\title{
IAMJ
}

INTERNATIONAL

AYURVEDIC

MEDICAL JOURNAL

Research Article

ISSN: 2320-5091

Impact Factor: 6.719

\section{AN OBSERVATIONAL STUDY TO ASSESS THE PARENTAL DOSHA PRAKRITI OF AUTISTIC CHILDREN}

\author{
Parvathy $\mathbf{S}^{1}$, Ananda Lakshmy $\mathrm{K}^{2}$ \\ ${ }^{1} 3^{\text {rd }}$ Year MD Scholar, Dept of Kriya Sareera, GAVC Kannur, Kerala, India \\ ${ }^{2}$ Professor and HOD, Dept of Kriya Sareera, GAVC, Thiruvananthapuram, Kerala, India
}

Corresponding Author: parvathynr58@gmail.com

\section{https://doi.org/10.46607/iamj0409122021}

(Published Online: December 2021)

Open Access

(C) International Ayurvedic Medical Journal, India

Article Received: 10/11//2021 - Peer Reviewed: 07/12/2021 - Accepted for Publication 08/12/2021

\section{Check for updates}

\begin{abstract}
Prakriti refers to the genetically determined physical and mental constitution of an individual. Autism is a lifelong disability identified by impaired communication, social interaction and repetitive behaviours. The genetic, environmental and immunological factors play an important role in generating autism. Genetic factors are more predominant in autism pathogenesis than the environmental factors that would modulate the phenotype. Until now, no interventions have proven widely effective in providing complete relief to autism. Therefore, the prevention of autism needs supreme attention. To a greater extent, prakriti of an individual can determine proneness to particular diseases. To assess the prakriti of both parents of 30 diagnosed cases of autistic children attending the OPD and IPD of Govt. Ayurveda College, Kannur were randomly selected. They are subjected to detailed history taking based on specially prepared proforma and assessments were recorded. Their prakriti assessment was done using a validated computer-assisted questionnaire software Ayusoft developed by C-DAC Pune. The data was statistically analysed. In this study, Vata pitta prakriti was significantly seen in mothers of autistic children.
\end{abstract}

Keywords: Prakriti, Autism 


\section{INTRODUCTION}

Classifying individuals according to prakriti is one of the unique features of Ayurveda. No two individuals are alike in this world. Personal variation is seen in physical, physiological and psychological aspects. Acharya Charaka mentioned prakriti pareeksha as first among dasavidha rogi pareeksha ${ }^{l}$.Prakriti is of two types sareera and manasa prakriti. The dosha dominant during the union of sperm and ovum determines prakriti ${ }^{2}$. It not only depends on it but also the diet and behaviour of the mother during pregnancy, time, intrauterine environment and mahabhutas ${ }^{3}$. Prakriti once formed remains constant throughout the life ${ }^{4}$ Knowing one's Prakriti helps to understand one's liking, disease proneness and prognosis, selection of medicines, drug response, diet and regimens making it one of the earliest known concepts of preventive and personalized medicine. Autism is a behavioural syndrome present from early life and is defined by deficient social interaction, language and communication, and play ${ }^{5}$. Till 1980, autism spectrum disorders were uncommon disorders but in recent times the numbers are increasing significantly, which may be due to the adoption of western lifestyle, prenatal stress, maternal complications, faulty diet and daily regimen. The exact cause of autism is unknown. Some studies attribute that the cause of autism is some gene abnormalities, prenatal factors, perinatal factors, \& some neurodevelopmental abnormalities ${ }^{6}$. Genetic factors are predominant in autism pathogenesis, in contrast with the environmental factors that would modulate the phenotype. Genetic research on families with multiple affected children and biochemical mechanism studies represent the sources for identifying the susceptibility of genes in autism. Environmental factors are also likely to interact with the genetic profile and cause an aberrant change in brain growth, neuronal development and functional connectivity ${ }^{7}$. According to WHO factsheet 2017, 1 in 160 children were affected with autism spectrum disorder ${ }^{8}$. The prevalence of autism in the United States is 1 in 59 now which was 1 in 68 two years back ${ }^{9}$. The principle of Prakriti in Ayurve$d a$ is based on heredity and genetics. Many studies to prove the role of genomes in the development of autism are still under process. Ayurvedic principles also emphasize the role of genetics in many developmental disorders. The link between parental events and the development of autism is speculative. Until now, no interventions have proven widely effective in providing complete relief to autism. Therefore, the prevention of autism needs supreme attention. Prevention of autism-like developmental disorders can be better attained by adopting measures to meet individual demands rather than adopting a generalised strategy. This individualised management can be well accomplished through the ayurvedic concept of prakriti. To a greater extent, prakriti of an individual can determine proneness to particular diseases. This study is intended to find out if parental prakriti influence autism. If the predominance of any of doshaprakriti among parents of autistic children was identified, proper preconception, prenatal, natal care can be advised with a suitable diet, regimen and lifestyle particular to that prakriti

\section{Methodology}

- Type of study - Observational study

- Study setting - GAVC, Kannur

- Study population - Parents of diagnosed cases of autistic children

- Sample size - 30

- Sampling technique - Random sampling

\section{INCLUSION CRITERIA}

- Parents of diagnosed autistic children who are willing to participate.

\section{EXCLUSION CRITERIA}

- Parents with intellectual disability

- Single parent

\section{Materials and methods}

1. Research proforma

2. Prakriti assessment tool - Ayusoft software ${ }^{10}$.

Research proforma contains questions containing demographic data, questionnaires containing preconception, prenatal, and natal and postnatal factors were assessed. 
Doshaprakriti of the subjects was assessed using validated computer-assisted questionnaire software Ayusoft, developed by C-DAC Pune.

The collected data were tabulated using SPSS 16.0 and analysed using appropriate statistical tests. Demographic data and other relevant information were analysed with descriptive statistics. Dosha Prakriti of the parents of autistic children was analysed using chi-square for the goodness of fit to evaluate the difference in the distribution of different types of Prakriti among parents of autistic children.

\section{STUDY TOOL}

Prakriti assessment of the participants was done with the help of validated computer-assisted questionnaire software. Questions are based on the classical guidelines regarding prakriti assessment. The software enables prakriti assessment with the help of a total of 83 questions that are age and gender-specific. Prakriti analysis in the software is performed using weightage configuration. Weightage ranging from 120 is provided for every question to predict the dosha. Characteristics that are exclusive for particular prakriti, and questions related to physique are given more weightage.

Prakriti is reported in software as a combination of predominant doshas based on \% score obtained for characteristics of each dosha

The resultant output from software displays individuals prakriti as a combination of doshas based on the percentage score obtained for each dosha characteristic. The software also provides supportive questions to reassess prakriti if the investigator is not satisfied with system detected prakriti

\section{OBSERVATIONS AND ANALYSIS}

Both the parents of 30 diagnosed cases of autistic children attending the OPD and IPD of Govt. Ayurveda College who fulfilled the inclusion criteria were selected for the study.
Demographic Data: Out of the 30 autistic children 22 were males and 8 were females. 17 parents out of 30 belonged to the middle class and 13 belonged to the lower class. 21 were from a rural area and 9 were urban areas. Among the 30 parents, $90.0 \%$ did not belong to consanguineous marriage and $10.0 \%$ belonged to consanguineous marriage. The majority of the fathers belonged to the 31-35 age group (44.5\%) and mothers belonged to $25-30$ years $(41.1 \%)$. Out of the 30 mothers, $53.3 \%$ had prenatal illness. $56 \%$ of the mothers experienced prenatal stress. $82.7 \%$ followed a mixed diet during pregnancy, $46.6 \%$ had a caesarean delivery. $16.6 \%$ of the autistic children had low birth weight.53.3\% of the autistic children had neonatal jaundice. $20 \%$ of the mothers stopped exclusive breastfeeding before 3 months.

Chart 1: Distribution according to the gender of the child

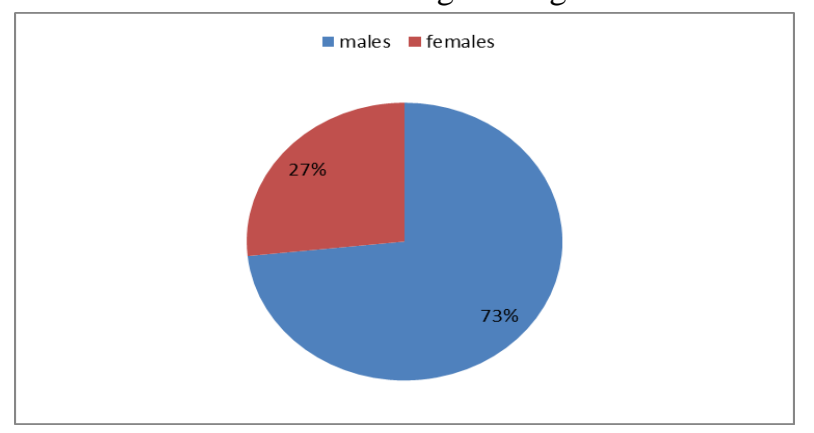

Chart 2: Distribution according to the socioeconomic status of parents

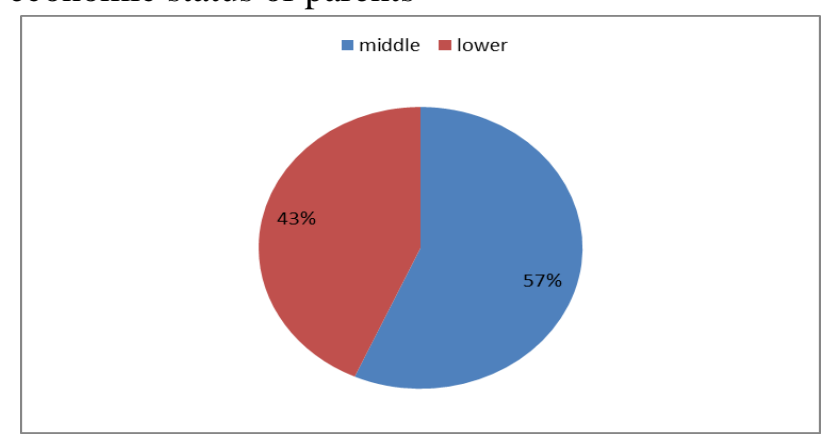


Table 1: Distribution according to consanguineous marriage

\begin{tabular}{|l|l|l|}
\hline Consanguineous marriage & Frequency & Percent \\
\hline Yes & 3 & 10.0 \\
\hline No & 27 & 90.0 \\
\hline Total & 30 & 100.0 \\
\hline
\end{tabular}

Table 2: Distribution according to paternal age at the time of conception

\begin{tabular}{|l|l|l|}
\hline Age & Frequency & Percent \\
\hline $25-30$ years & 12 & 40.0 \\
\hline $31-35$ years & 13 & 43.3 \\
\hline $36-40$ years & 5 & 16.6 \\
\hline Total & 30 & 100.0 \\
\hline
\end{tabular}

Table 3: Distribution according to maternal age at the time of conception

\begin{tabular}{|l|l|l|}
\hline Age & Frequency & \\
\hline $25-30$ years & 12 & 40.0 \\
\hline $31-35$ years & 11 & 36.6 \\
\hline $36-40$ years & 7 & 23.3 \\
\hline Total & 30 & 100.0 \\
\hline
\end{tabular}

Table 4: Distribution according to prenatal stress

\begin{tabular}{|l|l|l|}
\hline Prenatal stress & Frequency & Percent \\
\hline Present & 17 & 56.6 \\
\hline Absent & 13 & 43.3 \\
\hline Total & 30 & 100.0 \\
\hline
\end{tabular}

Table 5: Distribution according to prenatal illness

\begin{tabular}{|l|l|l|}
\hline Prenatal illness & Frequency & Percent \\
\hline Present & 16 & 53.3 \\
\hline Absent & 14 & 46.6 \\
\hline Total & 30 & 100.0 \\
\hline
\end{tabular}

Table 6: Distribution according to Diet during pregnancy

\begin{tabular}{|l|l|l|}
\hline Diet during pregnancy & Frequency & Percent \\
\hline Vegetarian & 5 & 16.6 \\
\hline Mixed & 25 & 83.3 \\
\hline Total & 30 & 100.0 \\
\hline
\end{tabular}

Table 7: Distribution according to Mode of labour

\begin{tabular}{|l|l|l|}
\hline Mode of labour & Frequency & Percent \\
\hline Normal vaginal & 12 & 40.0 \\
\hline Assisted & 5 & 16.6 \\
\hline LSCS & 13 & 43.3 \\
\hline Total & 30 & 100.0 \\
\hline
\end{tabular}


Table 8: Distribution according to Low birth weight

\begin{tabular}{|l|l|l|}
\hline Birth weight $(\mathrm{g})$ & Frequency & Percent \\
\hline Normal $(2500$ to 4500$)$ & 25 & 83.3 \\
\hline Low birth weight $(<2500)$ & 5 & 16.6 \\
\hline Total & 30 & 100.0 \\
\hline
\end{tabular}

Table 9: Distribution according to Exclusive breastfeeding

\begin{tabular}{|l|l|l|}
\hline Exclusive breastfeeding & Frequency & Percent \\
\hline$<3$ months & 6 & 20.0 \\
\hline $3-6$ months & 22 & 73.3 \\
\hline$>6$ months & 2 & 6.6 \\
\hline Total & 30 & 100.0 \\
\hline
\end{tabular}

\section{RESULT}

Prakriti analysis of fathers of autistic children using chi-square test goodness of fit for the testing difference in the distribution of different types of doshaprakriti showed a p-value of 0.392 which is $>0.005$ which is not statistically significant. This shows that there is no significant difference between the types of doshaprakriti of fathers of autistic children. Among fathers Vatapitta, Pittakapha, Vatakapha prakriti's were more and the variation was not statistically significant. Prakriti analysis of mothers of autistic children using chi-square test goodness of fit for the testing difference in the distribution of different types of doshaprakriti showed a p-value of 0.000 which is $<0.005$ which is statistically significant. This shows that there is a significant difference between the types of doshaprakriti of mothers of autistic children with $V P$ prakriti were seen more among mothers of autistic children.

\section{DISCUSSION}

Vata pitta prakriti was seen more among mothers of autistic children. Prakriti of a person is quite capable of providing a fair hint of physiological strengths and weaknesses, mental tendencies and susceptibility to illnesses of various types. The susceptibility to different diseases is influenced by the type of prakriti constitution in an individual. The dominant dosha has more impact on the physical and psychological qualities of a person. An individual is more affected by a disease that is influenced by the doshas which are predominant in the innate constitution. Autism is a neurodevelopmental disorder that has a strong genetic basis. In Ayurveda, all the psychosocial anomalies come together under the spectrum of unmada. Vatadosha is a prime factor responsible for the neurological as well as physiological functions of the body. The factors which lead to dushti of vata which is the most important reason in developing the features of autism. Diet and regimen during pregnancy and mental stress experienced by the mother had a direct effect on the psychological axis of the child. Regarding the psychological disorders of a child, Acharya has indicated to prevent this type of disorder not only from birth but also before birth considering the physical and psychological health of the mother. Most of the features seen in autism have similarities with Vatapitta vridhi lakshanas described in classics. Although Vatapitta prakriti is a normal condition, Aharavihara which can vitiate Vatapitta can cause autism condition. In this study, the gender-wise distribution shows that the majority of the children were boys (73\%) and $27 \%$ were girls. This study is consistent with the data analysis on gender by Rachel Loomes et al. came out with a male to female ratio of 3:1. As observed in the study, diagnosis ASD falls more in mothers between the age of 25-30 (40.0\%) and fathers between the ages of 31-35 (43.3\%) when compared to other age groups. There is numerous research conducted to find out the relation between parental age at the time of delivery and the prevalence of ASD since the possibility that autism is more common in offspring of older parents has significant importance in the prevention of diseases like autism. 
$56 \%$ of mothers experienced psychological stress during the time of pregnancy. Sattva, the psychological endowment of the child, is determined by the psychological state of mother and father during pregnancy, the behaviour of mother during pregnancy and Purva janmakrita karma. A community-based crosssectional study conducted in Kerala has come up with a caesarean section rate of $37.7 \%$. The rate of LSCS in the present study is much more $(43.3 \%)$ than the expected level. This study confirms previous findings that children born by LSCS are more likely to be diagnosed as having ASD. In this study, it was observed that $22 \%$ of the mother stopped exclusive breastfeeding before 3 months because of lack of milk production, due to occupation etc. This finding is in accordance with the meta-analysis reports stating that exclusive breastfeeding may protect against the risk of developing ASD.

\section{CONCLUSION}

Principles of prakriti in Ayurveda are based on heredity and genetics. An individual's constitution has a significant role in the susceptibility to particular diseases. Through various research was done to find out parental risk factors on autism. No studies have yet done to assess whether parental prakriti influence autism. The present study was conducted in both parents of 30 diagnosed cases of autistic children. This study shows that Vatapitta prakriti were more among the mothers of autistic children. Vatapitta prakriti shows a significant role in autism. So proper care can be taken before conception to avoid this type of condition.

\section{REFERENCES}

1. Dr. Ram Karan Sharma \& Vaidya Bhagwan Dash. Rogabhishakjitheyam vimanam. Agnivesh's Charaka Samhita. Varanasi: Chowkhamba Sanskrit Series;2015. pp. 261

2. Dr. Ram Karan Sharma \& Vaidya Bhagwan Dash. Rogabhishakjitheyam vimanam. Agnivesh's Charaka Samhita. Varanasi: Chowkhamba Sanskrit Series;2015. pp. 262
3. Prof. K.R Sreekanth Murthy. Prakritibhediya sareera. Ashtanga Samgraha of Vagbhata. Varanasi: Chowkhamba Orientalia ;2003. pp 98

4. Prof. K.R Sreekanth Murthy. Prakritibhediya sareera. Ashtanga Samgraha of Vagbhata. Varanasi: Chowkhamba Orientalia ;2003. pp 102

5. M S Mahadeviah. Childhood disabilities. A Parthasarathy et al (ed). IAP Textbook of Paediatrics, 4th ed. New Delhi: Jaypee Publishers \&Distributors Pvt Ltd; 2009. pp. 1053.

6. O P Ghai, Ramesh Agarwal, Naveen Sankhyan. Normal and abnormal development. OP Ghai, Vinod $\mathrm{k}$ Paul, Arvind Bagga (ed). Essential Pediatrics, 7th ed. New Delhi: CBC Publishers Distributors Pvt Ltd; 2009. pp. 40.

7. Roshini Anirudhan, M.A Shajahan. Gut-Brain Axis in Autism spectrum Disorders- Ayurvedic Perceptive. International Journal of Ayurveda and pharma Research.2028;6(11):29-38. Available from https://ijapr.in/index.php/ijapr/article /view/1093

8. WHO. Autism spectrum disorders. https://who.int/news-room/fact-sheets/detail/autismspectrum-disorders\# (accessed 7 November 2019).

9. Identified Prevalence of Autism Spectrum Disorders, ASD, CDC, Surveillance Summaries April 27,2018/67[3];1-23

http://www.cdc.gov/ncbddd/autism/data.html

10. Home page of CDAC: Centre for Development of Advanced Computing. Available from https://www.cdac.in/ 10.

\section{Source of Support: Nil \\ Conflict of Interest: None Declared}

How to cite this URL: Parvathy S \& Ananda Lakshmy K N: An Observational Study To Assess The Parental Dosha Prakriti Of Autistic Children. International Ayurvedic Medical Journal \{online\} 2021 \{cited December 2021\} Available from: http://www.iamj.in/posts/images/upload/2942_2947.pdf 